\title{
Osmoregulation in larvae and juveniles of two recently separated Macrobrachium species: Expression patterns of ion transporter genes
}

\author{
Boudour-Boucheker Nesrine ${ }^{1}$, Boulo Viviane ${ }^{2}$, Charmantier-Daures Mireille ${ }^{1}$, Anger Klaus ${ }^{3}$, \\ Charmantier Guy ${ }^{1}$, Lorin-Nebel Catherine ${ }^{1,{ }^{*}}$ \\ ${ }^{1}$ Université Montpellier, Adaptation Ecophysiologique et Ontogénèse, UMR9190 MARBEC, cc 092, \\ Place E. Bataillon, 34095 Montpellier cedex 05, France \\ 2 Ifremer, LEAD, BP2059, 98846 Nouméa Cedex, New Caledonia \\ ${ }^{3}$ Alfred-Wegener-Institut für Polar- und Meeresforschung, Biologische Anstalt Helgoland, 27498 \\ * Corresponding author : Catherine Lorin-Nebel, email address : catherine.lorin@umontpellier.fr
}

Helgoland, Germany

\begin{abstract}
:
In this comparative study, osmoregulatory mechanisms were analyzed in two closely related species of palaemonid shrimp from Brazil, Macrobrachium pantanalense and Macrobrachium amazonicum. A previous investigation showed that all postembryonic stages of $M$. pantanalense from inland waters of the Pantanal are able to hyper-osmoregulate in fresh water, while this species was not able to hypoosmoregulate at high salinities. In M. amazonicum originating from the Amazon estuary, in contrast, all stages are able to hypo-osmoregulate, but only first-stage larvae, late juveniles and adults are able to hyper-osmoregulate in fresh water. The underlying molecular mechanisms of these physiological differences have not been known. We therefore investigated the expression patterns of three ion transporters (NKA a-subunit, VHA B-subunit and NHE3) following differential salinity acclimation in different ontogenetic stages (stage-V larvae, juveniles) of both species. Larval NKA expression was at both salinities significantly higher in $M$. pantanalense than in $M$. amazonicum, whereas no difference was noted in juveniles. VHA was also more expressed in larvae of $M$. pantanalense than in those of $M$. amazonicum. When NHE3 expression is compared between the larvae of the two species, further salinity-related differences were observed, with generally higher expression in the inland species. Overall, a high expression of ion pumps in $M$. pantanalense suggests an evolutionary key role of these transporters in freshwater invasion.
\end{abstract}

Keywords : Salinity, Crustaceans, Branchial chamber, NHE3 transporter, V-type H+-ATPase, Na+/K+ATPase 


\section{Introduction}

Palaemonid shrimps are thought to originate from an ancestral tropical marine clade, which has shown a world-wide evolutionary tendency to adapt to non-marine conditions and successfully invade estuarine and limnic environments (review in Anger, 2013; Freire et al., 2003; Bauer, 2004; Augusto et al., 2009). Among those belonging to the genus Macrobrachium, M. amazonicum (Heller, 1862) has been considered as a particularly successful invader of South American freshwater habitats, showing an extremely wide range of geographic distribution in various hydrologically separated drainage systems. In recent years, however, a growing body of evidence suggested that " $M$. amazonicum" actually comprises at least two geographically and genetically distinct cryptic species (review in Weiss et al. 2015). One of these lives near the Amazon estuary, which is the type locality of $M$. amazonicum, another one is hololimnetic, living in landlocked inland waters (including the wetlands of the Pantanal region in southwestern Brazil) which drain to the La Plata River. Recent studies comparing shrimps from these two regions revealed biologically significant differences in various reproductive, developmental, morphometric, and ecological traits (Porto, 2004; Anger and Hayd, 2010; Urzúa and Anger, 2011; Hayd and Anger, 2013). Corresponding to their different life styles (estuarine versus hololimnic), significant differences were also found in adaptive physiological traits, especially in the osmoregulatory capabilities and structures of successive ontogenetic stages (Charmantier and Anger, 2011; Boudour-Boucheker et al., 2013). In hololimnetic shrimp from the Pantanal, all life-history stages are capable of hyper-osmoregulation in fresh water, while the function of hypoosmoregulation at high salt concentrations is completely absent (Charmantier and Anger, 2011). Pantanal shrimp, which previously had been considered as a population of $M$. amazonicum, were described as a separate species, M. pantanalense (dos Santos et al., 2013). Aquatic species living in or near to estuarine waters have to cope with wide salinity fluctuations. An elaborate mechanism of membrane transport processes facilitates at high salinities rapid removal of excess ions from the hemolymph, and at low salinities active ion absorption (Charmantier et al., 2009). The gills of marine and brackish-water crustaceans play a key role in the exchange of osmotically active substances between the environment and the hemolymph, thanks to the presence of specialized ion transporting cells (Lucu and Siebers, 1986). In palaemonid shrimps, ion transporters and channels are located in two different cell types within gill lamellae: septal and pillar cells (McNamara and Faria, 2012). $\mathrm{Na}^{+} / \mathrm{K}^{+}-$ ATPase (NKA), one of the driving forces facilitating transepithelial transport mechanisms, is located in the intralamellar septal cells (Boudour-Boucheker et al., 2013). The other driving force, particularly at low salinity, might be the V-type $\mathrm{H}^{+}$-ATPase (VHA) located in pillar 
cells, particularly in the apical plasma membrane and membrane vesicles (BoudourBoucheker et al., 2014).

Studies on different crustacean species have produced a variety of ion transport models (Lucu, 1990; Towle, 1990; Taylor and Taylor, 1992; Péqueux, 1995; Onken and Riestenpatt, 1998). Current models in palaemonid shrimps suggest that primary active excretion of $\mathrm{H}^{+}$via VHA drives secondary $\mathrm{Na}^{+}$absorption via an apical epithelial $\mathrm{Na}^{+}$Channel (ENaC) $(\mathrm{McNamara}$ and Faria, 2012). Other models in crustaceans propose the $\mathrm{Na}^{+} / \mathrm{K}^{+} / 2 \mathrm{Cl}^{-}$symporter or a $\mathrm{Na}^{+} / \mathrm{H}^{+}$ exchanger (NHE) as possible routes for apical $\mathrm{Na}^{+}$entry (McNamara and Faria, 2012). In palaemonid shrimps, septal cells express $\mathrm{Na}^{+} / \mathrm{K}^{+}$-ATPase (McNamara and Torres, 1999; Boudour-Boucheker et al., 2013) to drive $\mathrm{Na}^{+}$uptake, possibly sustained through $\mathrm{Na}^{+}$ transporters or channels in the pillar cells that have not been identified. $\mathrm{Na}^{+} / \mathrm{H}^{+}$exchangers (NHE) have been reported to be involved in $\mathrm{pH}$ homeostasis, cell volume regulation as well as transepithelial $\mathrm{Na}^{+}$transport (Wheatly and Gao, 2004). In teleost gills, $\mathrm{Na}^{+} / \mathrm{H}^{+}$exchangers appear to have similar functions to those of other vertebrates, namely exchanging one $\mathrm{Na}^{+}$for one $\mathrm{H}^{+}$(Claiborne et al., 2002). $\mathrm{Na}^{+} / \mathrm{H}^{+}$exchangers have also been studied in many invertebrate organisms and organs including crustacean crab gills (Carcinus maenas, Shetlar and Towle, 1989), lobster and prawn hepatopancreas (Homarus americanus, Ahearn and Clay, 1989; Macrobrachium rosenbergii, Ahearn et al., 1990). These studies suggest the presence of an electrogenic $\mathrm{Na}^{+} / \mathrm{H}^{+}$exchanger displaying a transport stoichiometry of $2 \mathrm{Na}^{+} / 1$ $\mathrm{H}^{+}$resulting in a polarization of membrane potential (Ahearn et al., 1990). This physiological property differs from those of vertebrate NHE where $\mathrm{Na}^{+}$uptake is achieved by electroneutral transport.

A NHE cDNA has been amplified and sequenced from gills of two crab species, Carcinus maenas and Callinectes sapidus (Newton et al., 1996; Towle et al., 1997). It is closely related to the vertebrate NHE isoforms previously sequenced, notably NHE3, but it is unknown whether this NHE is similar to the electrogenic exchanger described in membrane vesicles from crustacean epithelia (Shetlar and Towle, 1989; Pullikuth et al., 2003). In C. maenas, NHE is strongly expressed in gills, showing much lower abundance in all the other tissues examined: These findings suggest a role in acid-base regulation, volume regulation, or $\mathrm{Na}^{+}$ uptake (Towle et al., 1997). In decapodids, the presence of a branchial $\mathrm{Na}^{+} / \mathrm{H}^{+}$exchanger, possibly NHE3, might be important for palaemonid shrimps living in freshwater environments. Recurrent observations of conspicuously contrasting life-history traits suggest diversification in the two Macrobrachium species (Boudour-Boucheker et al., 2013; shortly before the taxonomical separation by dos Santos et al. (2013) referred to as different populations of $M$. amazonicum). These observations stimulated the present comparative study 
on gene expression patterns during ontogeny. In order to understand if there are different ion transport mechanisms involved, we have investigated the expression patterns of the NKA $\alpha$ subunit, the VHA B-subunit and the NHE3 following salinity acclimation and in different ontogenetic stages of M. amazonicum and M. pantanalense.

\section{Materials and methods}

\section{Origin and maintenance of animals}

Adult Macrobrachium amazonicum and M. pantanalense were obtained from the State University of Mato Grosso do Sul in Aquidauana (Mato Grosso do Sul, MS, Brazil). Shrimps were transported in cooling boxes to the Helgoland Marine Biological Laboratory (Germany), where they were kept in fresh water (FW; total ion concentration: $0.2 \mathrm{mg} / 1 ; 24^{\circ} \mathrm{C}$; for more details, see Anger and Hayd, 2010; Charmantier and Anger, 2011). Adult shrimps were fed frozen pieces of marine isopods (Idotea sp.) and commercial aquarium food (Novo Tab, JBL). Ovigerous females were maintained in aerated flow-through aquaria with 301 of FW. Newly hatched larvae were collected in sieves $(0.3 \mathrm{~mm}$ mesh size $)$ receiving the overflowing water and subsequently reared at 10 or $5 \mathrm{ppt}$ salinity (M. amazonicum and M. pantanalense, respectively), in aerated 11 beakers kept at $29^{\circ} \mathrm{C}$ and a 12:12 h light:dark cycle. Except for the zoea I stage, which is fully lecithotrophic, the larvae were fed freshly hatched Artemia sp. nauplii (Anger and Hayd, 2010).

\section{$\underline{\text { Salinity acclimations }}$}

Intermediate and late larval stages (zoea V, decapodids) were acclimated for $24 \mathrm{~h}$ either to brackish water $(5 \mathrm{ppt})$ or to slightly diluted seawater (DSW) (25 ppt). Three-week-old juveniles (referred to as early juveniles) were acclimated for $48 \mathrm{~h}$ either to $5 \mathrm{ppt}$ or to $25 \mathrm{ppt}$. Five-month-old juveniles (referred to as late juveniles) were stepwise transferred to FW (0.2 ppt) or to DSW (salinities 20 and $25 \mathrm{ppt}$ ) in which they were maintained for 2 weeks. After acclimation, all shrimps were anesthetized by speed freezing, then dissected and maintained in Trizol at $-80^{\circ} \mathrm{C}$ until analysis (see below).

The developmental stages and experimental salinities used in this study were chosen on the basis of previously observed differences in osmoregulatory capacities and survival rates (Charmantier and Anger, 2011), so that survival was always high enough to guarantee an availability of sufficient materials for sampling and measurements. In larvae, a minimal experimental salinity of 5 ppt was chosen because an acclimation to fresh water would have 
resulted in high mortalities; this medium was used only for late juveniles. Salinities of 20 and 25 ppt were selected to compare ion transport mechanisms in two species with different osmoregulatory strategies (hypoosmoregulator $v s$ osmoconformer).

\section{RNA extraction and cDNA synthesis}

Based on microscopic examinations of uropods, juveniles in stage $\mathrm{C}$ (intermolt stage) were selected. The small size and short molt cycle of larvae prevented microscopical routine moultstaging; however, larvae were sampled in the middle of each developmental stage, maximising the probability to select animals in stage C (see Hayd et al., 2008). For the extractions, whole larvae were used due to their small size. For early juveniles, only the cephalothorax with the gills, and for late juveniles only the gills were used. The tissues were cut in small pieces with sterile scalpels. Total RNA was extracted using Trizol reagent (Invitrogen, CergyPontoise, Val d'Oise, France) according to the manufacturer's instructions. Total RNA was treated with RNase-free DNase (Invitrogen) to remove any genomic DNA contamination. Quantification of total RNA was performed with a NanoDrop ${ }^{\circledR}$ ND-1000 V3300 Spectrophotometer (Nanodrop Technology Inc., Wilmington, Delaware, USA). Reverse transcription of $250 \mathrm{ng}$ of RNA was performed using M-MLV reverse transcriptase and random primers (Invitrogen) following the manufacturer's instructions. The resulting cDNA was stored at $-20^{\circ} \mathrm{C}$.

\section{NHE3 and EF1 $\alpha$ partial sequencing}

Degenerate primers (Table 1) were designed from Bioedit sequence alignments using nhe 3 sequences of several species including: Aedes aegypti (AF187723), Homo sapiens (NM_004174), Rattus norvegicus (NM_012654 XM_346529), Lepisosteus oculatus (JF19071), Eriocheir sinensis (AF301159), and Carcinus maenas (U09274). For Elongation Factor EF1 $\alpha$, a reference gene, the alignment included: Daphnia magna (AB734039.1), Alpheus thomasi (AF310826.1), Danio rerio (DQ083545.1), Palaemonetes varians (FJ654544.1), Litopenaeus vannamei (GU136229.1), Saccharomyces cerevisiae (M10992.1), Homo sapiens (NM_001402.5), and Mus musculus (NM_010106.2). For EF1 1 , degenerate primers previously tested on palaemonid shrimps were used (Ituarte et al., in press). Fifty $\mu 1$ of PCR product was then purified (Invitrogen) and sequenced using a BigDye ${ }^{\circledR}$ Terminator Sequencing Kit (Applied Biosystems, Foster City, CA, USA). All sequencing was performed on the Génotypage-Séquençage platform of IFR 119 (Montpellier, France) with an ABI Prism 3130 XL 16 capillary Genetic Analyzer instrument (Applied Biosystems). From these partial sequences, specific primers were designed for qPCR (Table 1). Dilution series of a cDNA 
mixture of several analyzed samples were performed in order to generate a standard curve and determine the efficiencies of each primer pair used in qPCR (Table 1).

\section{Quantification of NHE3, NKA and VHA expression by quantitative real-time PCR (qPCR)} The specific forward and reverse primers for the target genes, NKA $\alpha$-subunit and VHA Bsubunit were designed based on the published sequences in M. amazonicum (Faleiros et al., 2010). For NHE3 and EF1 $\alpha$, specific primers were designed from our sequenced fragments (Table 1). The qPCR analyses were performed with a Light-CyclerTM system version 3.5 (Roche, Mannheim, Baden-Württemberg, Germany), using $2.5 \mu \mathrm{l}$ of the LightCycler-FastStart DNA Master SYBR Green ITM Mix (Roche), $0.75 \mu \mathrm{L}$ of each primer (reverse and forward at $0.5 \mu \mathrm{M})$ and $1 \mu \mathrm{L}$ of diluted cDNA at $1 / 16$ corresponding to 0.74 ng equivalent RNA. The qPCR conditions were denaturation at $95^{\circ} \mathrm{C}$ for $10 \mathrm{~min}$, repeat of amplification $\left(95^{\circ} \mathrm{C}, 15 \mathrm{~s}\right)$, hybridization $\left(58^{\circ} \mathrm{C}, 5 \mathrm{~s}\right)$ and elongation $\left(72^{\circ} \mathrm{C}, 10 \mathrm{~s}\right) 40$ times, melting curve program at $60^{\circ} \mathrm{C}$ for $1 \mathrm{~min}$ and final cooling step at $40^{\circ} \mathrm{C}$ for $30 \mathrm{~s}$. For each primer couple, the efficiency was determined and the melting curve was analyzed in order to check the presence of only one amplification product. For each reaction, the crossing point (CP) was determined. All samples were analyzed in triplicate and the mean CP was calculated. The results were normalized with the reference gene EF1 $\alpha$. Ultra-pure water was used as a no-template control in the qPCR. The relative expression of NHE3, NKA and VHA were calculated for each condition (species, salinities and stages) using the advanced relative quantification method (eg. E-Method) of the ROCHE Lightcycler 480 software. This method has been used with the real efficiencies calculated before and including a standard in each run. Statistical analyses were performed on 13 animals per condition with one reading per individual.

\section{$\underline{\text { Statistical analysis }}$}

Pairwise comparisons using Wilcoxon rank sum test were performed to check the stability of the reference gene $(\mathrm{EF} 1 \alpha)$. To compare gene expression between salinities, stages and species, we used two-way analysis of variance (ANOVA). A significance level of $p<0.05$ was chosen.

\section{Results}

\section{$\underline{\text { Partial sequencing of EF1 } \alpha \text { and NHE3 }}$}

PCR amplification using degenerate primers resulted in a single amplification product of 262 bp and 495 bp for EF1 $\alpha$ and NHE3. The PCR product for each target gene was purified and 
sequenced. The respective nucleotide sequences were translated to ORFs that yielded highscoring BLAST matches to known amino acid sequences of EF1 $\alpha$ and NHE3 (Table 2). Macrobrachium amazonicum EF1 $\alpha$ and NHE3 sequences are available in GenBank under the accession numbers KU158862 and KU158863. The specific primers amplified a sequence of $163 \mathrm{bp}$ for EF1 $\alpha$ and 121 bp for NHE3 that were used for relative gene expressions (Table 1).

\section{$\underline{\text { Gene expression in larval and juvenile stages (NKA- } \alpha \text {, VHA and NHE3) }}$}

\section{NKA $\alpha$-subunit expression}

In the estuarine species Macrobrachium amazonicum, no significant salinity-related difference in the relative expression of NKA- $\alpha$ was found in the two larval stages studied (zoea V, decapodid), nor in early (Fig. 1) or late juveniles (Fig. 2).

In the inland species $M$. pantanalense, the zoea V stage showed, likewise, no difference in the relative expression of NKA- $\alpha$ at different salinities; in the decapodid and juvenile stages, however, a significant increase in NKA- $\alpha$ expression was observed after a direct exposure to 25 ppt salinity (Fig. 1A, B).

Interestingly, NKA- $\alpha$ expression was in all larval stages consistently higher in the inland than in the estuarine species, regardless of salinity, whereas no difference between species was noted in juveniles (Fig. 1B).

\section{VHA B-subunit expression}

In larval stages, VHA was slightly but consistently more expressed in $M$. pantanalense compared to M. amazonicum, except for the zoea V stage exposed to $25 \mathrm{ppt}$. No difference between salinities was noted, except for the zoea V of the in inland species, where VHA was more strongly expressed at 5 ppt salinity compared to 25 ppt (Fig. 1C).

In juveniles, VHA was in $M$. amazonicum, but not in $M$. pantanalense, more strongly expressed at 5 ppt compared to 25 ppt. Moreover, M. amazonicum, had higher VHA expression at $5 \mathrm{ppt}$ than the inland species (Fig. 1D).

In late juveniles, VHA expression was in the estuarine species higher in FW than at $25 \mathrm{ppt}$ salinity (Fig. 2).

\section{NHE3 expression}

In the zoea V stage of M. amazonicum, no difference in NHE3 expression was noted between salinities (Fig. 1E). In M. pantanalense, by contrast, the same larval stage showed a higher 
expression at $5 \mathrm{ppt}$ salinity compared to $25 \mathrm{ppt}$. A comparison between the two species shows an overall higher expression in the inland species exposed to $5 \mathrm{ppt}$. In the decapodid stage, the estuarine species had a higher NHE3 expression at 5 ppt salinity compared to $25 \mathrm{ppt}$ whereas the opposite pattern was observed in the inland species, with a stronger expression at 25 ppt. A difference was noted between the decapodids of the two species exposed to $25 \mathrm{ppt}$, with higher NHE3 expression in the inland species (Fig. 1E).

Early and late juveniles showed no significant salinity-dependent or species-specific differences in NHE3 expression (Figs. 1F, 2).

Comparing the expression of the three analyzed transporters in late juveniles of $M$. amazonicum, VHA was significantly higher expressed than NKA- $\alpha$ and NHE3, by about 4fold in FW and 2.5-fold at $25 \mathrm{ppt}$.

\section{Discussion}

\section{$\mathrm{Na}^{+} / \mathrm{K}^{+}$-ATPase (NKA)}

In the present study, we measured a consistently higher NKA- $\alpha$ expression in $M$. pantanalense (inland species) than in M. amazonicum (estuarine species) in the analyzed larval stages (zoea V and decapodid) at both salinities (5 and $25 \mathrm{ppt}$ ). However in the juvenile stage there was no difference between species. This result could be related to the developmental differences previously described between these two species: The larvae of the inland species show an accelerated gill development, along with an earlier development of ion transporting cells expressing NKA; these traits have been interpreted as an adaptation allowing for complete development in fresh water (Boudour-Boucheker et al., 2013). The branchial NKA is probably involved in $\mathrm{Na}^{+}$absorption from fresh water, which results in the possibility for this species to survive and live in this environment. In the estuarine species, the less expressed NKA, previously shown to be localized in the branchiostegites essentially, would be sufficient to drive ion transport in brackish water environments, but insufficient in FW.

In the inland species, differences in NKA- $\alpha$ expression between salinities were measured in decapodid and juvenile stages with higher expression at 25 ppt compared to 5 ppt salinity. Salinity-induced variations in NKA- $\alpha$ expression also occur in crab gill tissues (Lucu and Flik, 1999; Masui et al., 2005; Lovett et al., 2006). In the crab Chasmagnatus granulata, the transfer from a hyper-osmotic to a hypo-osmotic medium induced an increase in NKA- $\alpha$ 
expression (Luquet et al., 2005). However, NKA- $\alpha$ expression varies little in M. olfersi (Mendonça et al., 2007), Callinectes sapidus (Towle et al., 2001) and Scylla paramamosain (Chung and Lin, 2006), despite considerable alterations in specific activity of gill NKA. A discrepancy between transcript levels and protein activity suggests that post-transcriptional mechanisms are involved. Increased NKA activity and no change in transcript levels could thus be linked to mechanisms such as subunit assembly, membrane trafficking, or cell signaling. Faleiros et al. (2010) have also studied NKA $\alpha$-subunit expression in addition to enzyme activity following salinity transfer in an inland shrimp population referred to as " $M$. amazonicum". Their material was collected from an artificial lake in the state of São Paulo, Brazil (Paraná River system, draining to the La Plata, as in M. pantanalense). This species has thus probably the same hololimnic lifestyle as $M$. pantanalense. The relative expression of NKA- $\alpha$ in the gills of adult shrimps increased markedly during short term (1 h, $5 \mathrm{~h}, 1$ day) acclimation to $25 \mathrm{ppt}$ salinity. This pattern of salinity-induced variations in NKA- $\alpha$ expression has been observed in this study in the inland species after exposures during one day for larval stages and two days for juveniles. We can thus hypothesize that the regulation of NKA occurs at a transcriptional level after a short time and from the larval decapodid stage on; it is probably accomplished by hormonal modulation of NKA- $\alpha$ expression, a mechanism that is well documented in euryhaline fish species (McCormick, 1995) but less in crustaceans. In crustaceans, neuro-endocrine control of osmoregulation, demonstrated mostly in decapods (reviews in Mantel and Farmer, 1983; Péqueux, 1995; Charmantier et al., 2009), is probably effected by $\mathrm{CHH}$, the Crustacean Hyperglycemic Hormone (Charmantier-Daures et al., 1994; Spannings-Pierrot et al., 2000), along with dopamine, and cAMP probably involved as second messenger, both able to modulate NKA activity (Liu et al., 2008; review in Charmantier et al. 2009). These results imply that the energetic costs of hypo-osmoregulation under stressful conditions are met, at least in part, by enhanced NKA- $\alpha$ expression. The increase in NKA- $\alpha$ expression in decapodid and early juvenile stages exposed to high salinity could also be related to the synthesis of new enzymes necessary for the preparation and successful transition during the metamorphic molt. According to Faleiros et al. (2010), following a longterm (5-10 days) salinity acclimation to $25 \mathrm{ppt}$, branchial NKA activity is lower than in fresh water, while expression values are comparable to those in fresh water. From these results, as well as from ours, we can suggest that in the hololimnic inland species, NKA- $\alpha$ expression increases following a direct exposure to high salinities and decreases afterwards to values observed in fresh water. NKA is thus essential for both hyper- and hypo-ionic regulation as shown in many euryhaline crustaceans (Charmantier et al., 2009). In the estuarine species, by contrast, no effect of salinity on NKA- $\alpha$ expression has been found during ontogeny. Leone et 
al., 2014 have demonstrated changes in NKA activity during the ontogeny of M. amazonicum (estuarine species). They suggested that the kinetic behavior of NKA may be stage-specific, possibly correlating with the biochemical adjustment of each ontogenetic stage to the optimal salinity found in its natural environment. We hypothesize that in the estuarine species, unlike inland species, NKA regulation occurs essentially at post-translational level. This difference in gene expression between both species could be due to different adaptive strategies linked to different habitats. Indeed, $25 \mathrm{ppt}$ salinity represents for the inland species an osmotic challenge that it never faces in its natural habitat. The estuarine species, however, is more adapted to salinity variations owing to its diadromous migrations.

\section{V-type $\mathrm{H}^{+}$-ATPase (VHA)}

The V-type $\mathrm{H}^{+}$-ATPase appears as a key enzyme for osmoregulation in many organisms (Beyenbach, 2001; Kirschner, 2004; Covi and Hand, 2005). In hyper-osmoregulating freshwater crustaceans, amphibians and fish, VHA seems to be involved in driving ion uptake (Wieczorek et al., 1999; Nelson and Harvey, 1999; Kirschner, 2004; Beyenbach and Wieczorek, 2006), as also shown by studies on gene expression and protein activities (Faleiros et al., 2010; Lee et al., 2011; Towle et al., 2011). In Eurytemora affinis, a copepod known as a rapid freshwater invader, freshwater populations exhibited a higher increase in VHA activity in fresh water versus 15 ppt compared to saline populations (Lee et al., 2011). Higher VHA expression in the larval stages of $M$. pantanalense, which develop in fresh water under natural conditions, may be related to an increased need to energize active ion uptake in fresh water by excreting $\mathrm{H}^{+}$to the external medium. The high larval capacity of this inland species to hyper-osmoregulate in fresh water (Charmantier and Anger, 2011) could be sustained by the capacity of expressing higher amounts of VHA than in estuarine larvae. In the zoea V stage of M. pantanalense, in which gill lamellae have developed, VHA expression is higher at $5 \mathrm{ppt}$ than at $25 \mathrm{ppt}$ salinity. In adult $M$. amazonicum gills, a striking decrease in VHA activity and expression has been observed 10 days after acclimation of the shrimps from FW to 21 ppt (Santos et al., 2007; Faleiros et al., 2010). In decapodid and juvenile stages of $M$. pantanalense, the absence of salinity-induced differences in VHA expression may be related to the short acclimation time ( $24 \mathrm{~h}$ for decapodids and $48 \mathrm{~h}$ for juveniles). Longer-term salinity acclimation is prevented by the short duration of the early life-history stages.

In the estuarine species, M. amazonicum, VHA expression did not vary between larval stages. These stages cannot survive in fresh water, probably partly due to the absence of VHA gene transcription following salinity change. This VHA expression pattern may originates from an 
incomplete gill development reported in a previous study (Boudour-Boucheker et al., 2013). In contrast, in both early and late juveniles, the gills are well developed, and VHA is more expressed at $5 \mathrm{ppt}$ and FW compared to $25 \mathrm{ppt}$. Interestingly, VHA seems of particular importance in these more advanced developmental stages of $M$. amazonicum, since its expression is 2.5 and 4 times higher than the other analyzed genes at $25 \mathrm{ppt}$ and in FW. This result supports the importance of branchial VHA in hyper-osmoregulation and salinity adaptation, in relation to the ecology of the estuarine species, whose juvenile stages live in fresh water and thus need an efficient ion uptake, possibly via transporters such as NHE or the epithelial $\mathrm{Na}^{+}$channel ENaC.

\section{$\mathrm{Na}^{+} / \mathrm{H}^{+}$exchanger (NHE3)}

Due to the functional distinction in the stoichiometry $\left(2 \mathrm{Na}^{+} / 1 \mathrm{H}^{+} v s 1 \mathrm{Na}^{+} / 1 \mathrm{H}^{+}\right)$of exchange in the crustacean forms, further molecular studies are required on the electrogenic and electroneutral $\mathrm{Na}^{+} / \mathrm{H}^{+}$exchanger (NHE) of decapods (Towle et al., 1997). To our knowledge, this is the first report of NHE3 in a palaemonid shrimp. In crustaceans, NHEs have been detected in the hepatopancreas of lobsters (Ahearn and Clay, 1989) and shrimp, in Peneaus japonicus (Vilella et al., 1998), and also in the gills of crabs, Callinectes sapidus (Shetlar and Towle, 1989) and Carcinus meanas (Towle et al., 1997). Studies on crustacean and echinoderm brush border membrane vesicles of gut, kidney and gill epithelia suggest the presence of an electrogenic $\mathrm{Na}^{+} / \mathrm{H}^{+}$ion exchanger with a transport stoichiometry of $2 \mathrm{Na}^{+} / 1 \mathrm{H}^{+}$ (Ahearn and Clay, 1989; Shetlar and Towle, 1989; Ahearn and Franco, 1990 and 1991; Ahearn et al., 1990). Using crustacean gut cells, the presence of two external cation-binding sites with dissimilar binding properties was shown kinetically through external inhibition of $\mathrm{Na}^{+}$transport (Ahearn and Clay, 1989; Ahearn and Franco, 1990 and 1991). It has also been reported that this electrogenic system transports $\mathrm{Ca}^{2+}$. The transport of $\mathrm{Ca}^{2+}$ and $\mathrm{Na}^{+}$, considered as competitive inhibitors, was blocked by amiloride, an inhibitor of NHE (Ahearn and Franco, 1990). In the present study, species-specific differences in NHE3 expression occur in larval Macrobrachium exposed to different salinities, with generally stronger expression in the inland species, $M$. pantanalense. These results do not permit to confirm the involvement of NHE3 in $\mathrm{Na}^{+}$uptake in low salinity media. Other secondary transporters such as $\mathrm{ENaC}$ might conduct VHA-driven $\mathrm{Na}^{+}$uptake.

As a shrimp approaches molting, part of the $\mathrm{Ca}^{2+}$ that is contained in the exoskeleton is transferred to the hemolymph across the gills and other permeable sites, or stored in epithelial cells (Greenaway, 1985). Following ecdysis, the stored $\mathrm{Ca}^{2+}$ is again transferred to 
hemolymph then to the tegument and the newly formed exoskeleton, possibly through NHE3 (Neufeld and Cameron, 1993; Flik and Haond, 2000). As the molting stage was not precisely controlled in larvae, different molting stages among the animals could partly account for the differences observed in NHE3 expression. Other factors such as intracellular pH could also affect gene expression levels (Wheatly and Gao, 2004). Brett et al. (2005) identified a new family of related genes called NHA. Future investigations on regulatory mechanisms, structural components and cellular localization should clarify the precise physiological role of $\mathrm{Na}^{+} / \mathrm{H}^{+}$antiporters in Macrobrachium shrimps.

In conclusion, a functional difference between M. amazonicum and M. pantanalense is reported in this study, regarding genes involved in ion transport and their regulatory level. The expression of the main ion pumps NKA, VHA, and to a lesser extent NHE3, is higher in the larval stages of $M$. pantanalense than in M. amazonicum, in relation to their different life styles: The former spends its entire life cycle in fresh water while early development stages of the latter are exposed to estuarine salinity variations. The difference in expression of transporters also reflects developmental differences between the two species (BoudourBoucheker et al., 2013). The strategy of rapid development of functional gills expressing the main ion pumps in the larvae of $M$. pantanalense is probably the major factor allowing this species to survive in fresh water, where its entire life cycle occurs. In addition, the capacity to produce hypotonic urine demonstrated in juveniles of both species and resulting from ionic reabsorption in the excretory antennal glands (Charmantier, unpublished results) probably contributed to the acquisition of hyper-osmoregulation in all larval stages of $M$. pantanalense. Selection pressure operating through successive generations led to a loss of hypoosmoregulation in salt water, which is no longer needed by a hololimnetic species. In the estuarine species, in contrast, this function is still essential during the larval development in estuarine salt waters.

\section{Aknowledgments}

The authors would like to thank the Algerian ministry of scientific research for partial funding of this work, Romina Ituarte for providing degenerate primers of EF1 $\alpha$, Liliam Hayd (State Univertsity of Mato Grosso do Sul, Brazil) for transporting live adult shrimp from Brazil to Helgoland, and Uwe Nettelmann, Alfred Wegener Institut, Helgoland, for larval rearing. 


\section{References}

Ahearn, G.A., Clay, L.P., 1989. Kinetic analysis of electrogenic $2 \mathrm{Na}^{+} / 1 \mathrm{H}^{+}$antiport in crustacean hepatopancreas. Am. J. Physiol. 257, 484-493.

Ahearn, G.A., Franco, P., 1990. $\mathrm{Na}^{+}$and $\mathrm{Ca}^{2+}$ share the electrogenic $2 \mathrm{Na}^{+} / 1 \mathrm{H}^{+}$antiporter in crustacean antennal glands. Am. J. Physiol. 259, 759-767.

Ahearn, G.A., Franco, P., Clay, L.P., 1990. Electrogenic $2 \mathrm{Na}^{+} / 1 \mathrm{H}^{+}$exchange in crustaceans. J. Membr. Biol. 116, 215-226.

Ahearn, G.A., Franco, P., 1991. Electrogenic $2 \mathrm{Na}^{+} / 1 \mathrm{H}^{+}$antiport in echinoderm gastrointestinal epithelium. J. Exp. Biol. 158, 495-507.

Anger, K., Hayd, L., 2010. Feeding and growth in early larval shrimp Macrobrachium amazonicum from the Pantanal, southwestern Brazil. Aquat. Biol. 9, 251-261.

Anger, K., 2013. Neotropical Macrobrachium (caridea: palaemonidae): on the biology, origin, and radiation of freshwater-invading shrimp. J. Crust. Biol. 33, 151-183.

Augusto, A., Silva, P.A., Greene, L.J., Laure, H.J., McNamara J.C., 2009. Evolutionary transition to freshwater by ancestral marine Palaemonids: evidence from osmoregulation in a tide pool shrimp. Aquat. Biol. 7, 113-122.

Bauer, R.T., 2004. Remarkable shrimps: adaptations and natural history of the carideans. University of Oklahoma Press, Norman, 316 p.

Beyenbach, K., 2001. Energizing epithelial transport with the vacuolar $\mathrm{H}^{+}$ATPase. News in Physiol. Sci. 16, 145-151.

Beyenbach, K., Wieczorek, H., 2006. The V-type $\mathrm{H}^{+}$-ATPase: molecular structure and function, physiological roles and regulation. J. Exp. Biol. 209, 577-589.

Boudour-Boucheker, N., Boulo, V., Lorin-Nebel, C., Elgero, C., Grousset, E., Anger, K., Charmantier-Daures, M., Charmantier, G., 2013. Adaptation to freshwater in the palaemonid shrimp Macrobrachium amazonicum: comparative ontogeny of osmoregulatory organs. Cell Tissue Res. 353, 87-98.

Boudour-Boucheker, N., Boulo, V., Charmantier-Daures, M., Grousset, E., Anger, K., Charmantier, G., Lorin-Nebel, C., 2014. Differential distribution of V-H $\mathrm{H}^{+}$type ATPase and $\mathrm{Na}^{+} / \mathrm{K}^{+}$ATPase in the branchial chamber of the shrimp Macrobrachium amazonicum. Cell Tissue Res. 357, 195-206.

Brett, C.L., Donowitz, M., Rao, R., 2005. Evolutionary origins of eukaryotic sodium/proton exchangers. Am. J. Physiol. Cell Physiol. 288, C223-C239.

Charmantier, G., Charmantier-Daures, M., Towle, D.W., 2009. Osmotic and ionic regulation in aquatic arthropods. In: Evans, D.H. (Ed.) Osmotic and Ionic Regulation: Cells and Animals. Taylor \& Francis Group, London, pp. 165-208. 
449 Charmantier, G., Anger, K., 2011. Ontogeny of osmoregulatory patterns in the South 450 American shrimp Macrobrachium amazonicum: loss of hyporegulation in a land-locked 451 population indicates phylogenetic separation from estuarine ancestors. J. Exp. Mar. Biol. 452 Ecol. 396, 89-98.

453 Charmantier-Daures, M., Charmantier, G., Janssen, K.P.C., Aiken, D.E., Van Herp, F., 1994. 454 Involvement of eyestalk factors in the neuroendocrine control of hydromineral metabolism in 455 adult American lobster Homarus americanus. Gen. Comp. Endocrinol. 94, 281-293.

456 Chung, K.F., Lin, H.C., 2006. Osmoregulation and $\mathrm{Na}^{+} / \mathrm{K}^{+}$ATPase expression in 457 osmoregulatory organs of Scylla paramamosain. Comp. Biochem. Physiol. 144, 48-57.

458 Claiborne, J.B., Edwards, S.L., Morrison-Shetlar, A.I., 2002. Acid-base regulation in fishes: 459 cellular and molecular mechanisms. J. Exp. Zool. 293, 302-319.

460 Covi, J.A., Hand, S.C., 2005. V-ATPase expression during development of Artemia 461 franciscana embryos: potential role for proton gradients in anoxia signaling. J. Exp. Biol. 208, $462 \quad 2783-2798$.

463 Dos Santos, A., Hayd, L., Anger, K., 2013. A new species of Macrobrachium Spence Bate, 4641868 (Decapoda, Palaemonidae), M. pantanalense, from the Pantanal, Brazil. Zootaxa 3700, 465 534-546.

466 Duerr, J.M., Ahearn, G.A., 1996. Characterization of a basolateral electroneutral 467 $\mathrm{Na}^{+} / \mathrm{H}^{+}$antiporter in Atlantic lobster (Homarus americanus) hepatopancreatic epithelial vesicles. J. Exp. Biol. 199, 643-651. Faleiros, R.O., Goldman, M.H.S., Furriel, R.P.M., McNamara, J.C., 2010. Differential adjustment in gill $\mathrm{Na}^{+} / \mathrm{K}^{+}$and $\mathrm{V}$-ATPase activities and transporter mRNA expression during osmoregulatory acclimation in the cinnamon shrimp Macrobrachium amazonicum (Decapoda, Palaemonidae). J. Exp. Biol. 213, 3894-3905.

473 Flik, G., Haond, C., 2000. $\mathrm{Na}^{+}$and $\mathrm{Ca}^{2+}$ pumps in the gills, epipodites and branchiostegites of 474 the European lobster Homarus gammarus: effects of dilute seawater. J. Exp. Biol. 203, 213475220.

476 Freire, C.A., Cavassin, F., Rodrigues, E.N., Torres, A.H., McNamara, J.C., 2003. Adaptive 477 patterns of osmotic and ionic regulation, and the invasion of fresh water by the palaemonid 478 shrimps. Comp. Biochem. Physiol. Mol. Integr. Physiol. 136, 771-778.

479 Greenaway, P. 1985. Calcium balance and moulting in the crustacean. Biol. Rev. 60, 425 $480-454$.

481 Hayd, L., Anger, K., 2013. Reproductive and morphometric traits of Macrobrachium 482 amazonicum (Decapoda, Palaemonidae) from the Pantanal, Brazil, suggests initial speciation. 483 Revista de Biologia Trop. 61, 39-57. 
Hayd, L.A., Anger, K., Valenti, W.C., 2008. The moulting cycle of larval Amazon River prawn Macrobrachium amazonicum reared in the laboratory. Nauplius 16, 55-63.

Ituarte, R., Lignot J.-H., Charmantier G., Spivak, E., Lorin-Nebel C. Immunolocalization and expression of $\mathrm{Na}^{+} / \mathrm{K}^{+}$-ATPase in embryos, early larval stages and adults of the freshwater shrimp Palaemonetes argentinus (Decapoda, Caridea, Palaemonidae). Cell Tiss. Res. (in press).

Kirschner, L.B., 2004. The mechanism of sodium chloride uptake in hyper regulating aquatic animals. J. Exp. Biol. 207, 1439-1452.

Lee, C.E., Kiergaard, M., Gelembiuk, G.W., Eads, B.D., Posavi, M., 2011. Pumping ions: rapid parallel evolution of ionic regulation following habitat invasions. Evolution 65, 22292244.

Leone, F.A., Bezerra, T.M.S., Garçon, D.P., Lucena, M.L., Pinto, M.R., Fontes, C.F.L., McNamara J.C., 2014. Modulation by $\mathrm{K}^{+}$plus $\mathrm{NH}^{+}$of microsomal $\left(\mathrm{Na}^{+}, \mathrm{K}^{+}\right)$-ATPase activity in selected ontogenetic stages of the diadromous river shrimp Macrobrachium amazonicum (Decapoda, Palaemonidae). PLoS ONE 9: e89625.

Liu, H.Y.L., Pan, Q., Zheng, D.B., 2008. Injection of biogenic amines modulates osmoregulation of Litonpenaeus vannamei. Response of hemolymph osmotic pressure, ion concentration and osmolality effectors. Comp. Biochem. Physiol. A 151, 191-197.

Lovett, D.L., Colella, T., Cannon, A.C., Lee, H., Evangelisto, A., Muller, E.M., Towle, D.W., 2006. Effect of salinity on osmoregulatory patch epithelia in gills of the blue crab Callinectes sapidus. Biol. Bull. 210, 132-139.

Lucu, C., Siebers, D., 1986. Amiloride-sensitive sodium flux and potentials in perfused Carcinus gill preparations. J. Exp. Biol. 122, 25-35.

Lucu, C., 1990. Ionic regulatory mechanisms in crustacean gill epithelia. Comp. Biochem. Physiol. 97A, 297-306.

Lucu, C., Flik, G., 1999. $\mathrm{Na}^{+}-\mathrm{K}^{+}$-ATPase and $\mathrm{Na}^{+} / \mathrm{Ca}^{2+}$ exchange activities in gills of hyperregulating Carcinus maenas. Am. J. Physiol. 276, 490-499.

Luquet, C.M., Weihrauch, D., Senek, M., Towle, D.W., 2005. Induction of branchial ion transporter mRNA expression during acclimation to salinity change in the euryhaline crab Chasmagnathus granulatus. J. Exp. Biol. 208, 3627-3636.

Mantel, L.H., Farmer L.L., 1983. Osmotic and ionic regulation. In: Mantel L.H. (Ed.) Internal anatomy and physiological regulation. Academic Press, New York, pp. 53-161.

Masui, D.C., Furriel, R.P.M., Mantelatto, F.L.M., McNamara, J.C., Leone, F.A., 2005. K phosphatase activity of gill $\left(\mathrm{Na}^{+}, \mathrm{K}^{+}\right)$ATPase from the blue crab, Callinectes sapidus danae: low-salinity acclimation and expression of the $\alpha$-subunit. J. Exp. Zool. 303, 294-307. 
519 McCormick, S.D., 1995. Hormonal control of gill $\mathrm{Na}^{+}, \mathrm{K}^{+}$-ATPase and chloride cell function. 520 In: Fish Physiology, Ionoregulation: Cellular and Molecular Approaches. Wood C.M. and 521 Shuttleworth T.J. (Eds). New York, Academic Press, Vol. XIV, 285-315.

522 McNamara, J.C., Lima, A.G., 1997. The route of ion and water movements across the gill 523 epithelium of the freshwater shrimp Macrobrachium olfersii (Decapoda, Palaemonidae): 524 evidence from ultrastructural changes induced by acclimation to saline media. Biol. Bulletin $525192,321-331$.

526 McNamara, J.C., Torres, A.H., 1999. Ultracytochemical location of $\mathrm{Na}^{+} / \mathrm{K}^{+}$-ATPase activity 527 and effect of high salinity acclimation in gill and renal epithelia of the freshwater shrimp 528 Macrobrachium olfersii (Crustacea, Decapoda). J. Exp. Zool. 284, 617-628.

529 McNamara, J.C., Faria, S.C., 2012. Evolution of osmoregulatory patterns and gill ion 530 transport mechanisms in the decapod Crustacea: a review. J. Comp. Physiol. 182, 997-1014.

531 Mendoça, N.N, Masui, D.C., McNamara, J.C., Leone, F.A., Furriel, R.P.M., 2007. Long-term 532 exposure of the freshwater shrimp Macrobrachium olfersii to elevated salinity: Effects on gill $533\left(\mathrm{Na}^{+}, \mathrm{K}^{+}\right)$-ATPase $\alpha$-subunit expression and $\mathrm{K}^{+}$-phosphatase activity. Comp. Biochem. 534 Physiol. 146, 534-543.

535 Nelson, N., Harvey, W., 1999. Vacuolar and plasma membrane proton536 adenosinetriphosphatases. Physiol. Rev. 79, 361-385.

537 Neufeld, D.S., Cameron, J.N., 1993. Transepithelial movement of calcium in crustaceans. J. 538 Exp. Biol. 184, 1-16.

539 Newton, C.R., Tilghman, J.A., Towle, D.W., 1996. Direct sequencing of PCR amplified $540 \mathrm{Na}^{+} / \mathrm{H}^{+}$-antiporter cDNA from the blue crab Callinectes sapidus. Bull. Mount Desert Island 541 Biol. Lab. 35: 19-21.

542 Onken, H., Riestenpatt, S., 1998. $\mathrm{NaCl}$ absorption across split gill lamellae of hyperregulating 543 crabs: transport mechanisms and their regulation. Comp. Biochem. Physiol. 119, 883-893.

544 Péqueux, A., 1995. Osmotic regulation in crustaceans. J. Crust. Biol. 15, 1-60.

545 Porto, L.A.C., 2004. Estudos morfológico sem populações do complex Macrobrachium 546 amazonicum (Heller, 1862) (Crustacea, Decapoda, Palaemonidae) emdiferent esbacias 547 hidrográficas brasileiras. Ph.D Thesis. University of São Paulo, Brazil, 170 p.

548 Pullikuth, A.P., Filippov, V., Gill, S.S., 2003. Phylogeny and cloning of ion transporters in 549 mosquitoes. J. Exp. Biol. 206, 3857-3868.

550 Santos, L.C.F., Belli, N.M., Augusto, A., Masui, D.C., Leone, F.A., McNamara, J.C., Furriel, 551 R.P.M., 2007. Gill $\left(\mathrm{Na}^{+}, \mathrm{K}^{+}\right)$-ATPase in diadromous, freshwater palaemonid shrimps: 552 Species-specific kinetic characteristics and $\alpha$-subunit expression. Comp. Biochem. Physiol. $553148,178-188$. 
554 Shetlar R.E., Towle, D.W., 1989. Electrogenic sodium-proton exchange in membrane vesicles

555 from crab (Carcinus maenas) gill. Am. J. Physiol. 257, 924-931.

556 Spanings-Pierrot, C., Soyez, D., Van Herp, F., Gompel, M., Skaret, G., Grousset, E.,

557 Charmantier, G., 2000. Involvement of Crustacean Hyperglycemic Hormone in the control of

558 gill ion transport in the crab Pachygrapsus marmoratus. Gen. Comp. Endocrinol. 119, 340559350.

560 Taylor, H.H., Taylor, E.W., 1992. Gills and lungs: the exchange of gases and ions. In:

561 Microscopic Anatomy of Invertebrates. Harrison, F.W., Humes, A.G. (Eds). Wiley-Liss, New

562 York, 203-343.

563 Towle, D.W., 1990. Sodium transport systems in gills. In: Comparative aspects of sodium 564 cotransport systems. Kinne, R.K.H. (Ed.). Karger Publishing, Basel, pp. 241-263.

565 Towle, D.W., Rushton, M.E., Heidysch, D., Magnani, J.J., Rose, M.J., Amstutz, A., Jordan, 566 M.K., Shearer, D.W., Wu, W.S., 1997. Sodium/Proton antiporter in the euryhaline crab 567 Carcinus maenas: molecular cloning, expression and tissue distribution. J. Exp. Biol. 200, 568 1003-1014.

569 Towle, D.W., R.S. Paulsen, D. Weihrauch, M. Kordylewski, C. Salvador, J.H. Lignot, C. 570 Spanings-Pierrot (2001). $\mathrm{Na}^{+}, \mathrm{K}^{+}$-ATPase in gills of the blue crab Callinectes sapidus: cDNA 571 sequencing and salinity-related expression of a-subunit mRNA and protein. J. Exp. Biol. $572 \quad 204: 4005-4012$.

573 Towle, D.W., R.P. Henry, N.B.T Erwilliger (2011). Microarray-detected changes in gene 574 expression in gills of green crabs (Carcinus maenas) upon dilution of environmental salinity. 575 Comp. Biochem. Physiol. 6: 115-125.

576 Urzúa, Á., Anger, K., 2011. Larval biomass and chemical composition at hatching in two 577 geographically isolated clades of the shrimp Macrobrachium amazonicum: intra- or 578 interspecific variation? Invertebrate Reproduction \& Development 55, 236-246.

579 Vilella, S., V. Zonno, L. Ingrosso, T. Verri, C. Storelli (1998). Electroneutral $\mathrm{Na}^{+} / \mathrm{H}^{+}$ 580 exchange in brush-border membrane vesicles from Penaeus japonicas hepatopancreas. Am. 581 Physiol. Society, 486-493.

582 Weiss, R., Anger, K., Hayd, L., Schubart, C.D., 2015. Interpreting genetic distances for 583 species recognition: the case of Macrobrachium amazonicum Heller, 1862 and the recently 584 described M. pantanalense dos Santos, Hayd \& Anger, 2013 (Decapoda, Palaemonidae) from 585 Brazilian fresh waters. Crustaceana 88, 1111-1126.

586 Wheatly, M.G., Y. Gao (2004). Molecular biology of ion motive proteins in comparative 587 models. J. Exp. Biol. 207: 3253-3263. 
588 Wieczorek, H., G. Gruber, W.R. Harvey, M. Huss, H. Merzendorfer (1999). The plasma 589 membrane $\mathrm{H}^{+}-\mathrm{V}$-ATPase from tobacco hornworm midgut. J. Bioenergetics Biomembr. 31: $590 \quad 67-74$.

591 


\section{Figure legends}

593

594 Fig. 1: Relative expression of NKA- $\alpha$ (A, B), VHA (C, D) and NHE3 (E, F) in larvae (zoea $595 \mathrm{~V}$, decapodid) (A, C, E) and juveniles (B, D, F) of Macrobrachium amazonicum (A; estuarine 596 species) and M. pantanalense (P; inland species) acclimated to 5 and 25 ppt salinity. Results 597 are expressed as mean \pm SEM; different letters indicate significant differences. ZV: zoea V; 598 D: decapodid; JB: juvenile branchial chamber.

599

600 Fig. 2: Relative expression of NKA- $\alpha$, VHA and NHE3 in late juveniles of Macrobrachium 601 amazonicum (estuarine species) acclimated to fresh water (FW) and 25 ppt salinity. Results 602 are expressed as the mean \pm SEM. Different letters indicate significant differences.

603

604

\section{Table legends}

605 Table 1: Primer sequences used in this study. CS : primers used for cloning and sequencing; $606 \mathrm{~d}$ : degenerate primers; $\mathrm{F}$ : forward, qPCR : primers used for qPCR; R : reverse. The 607 sequences used standard IUPAC code : R : A/G, Y : C/T, W : A/T.

608

Table 2: Percentage amino acid homology of Macrobrachium amazonicum EF1 $\alpha$ and NHE3 609 partial sequences. Homologies were calculated according to the blastp algorithm. 
Fig. 1
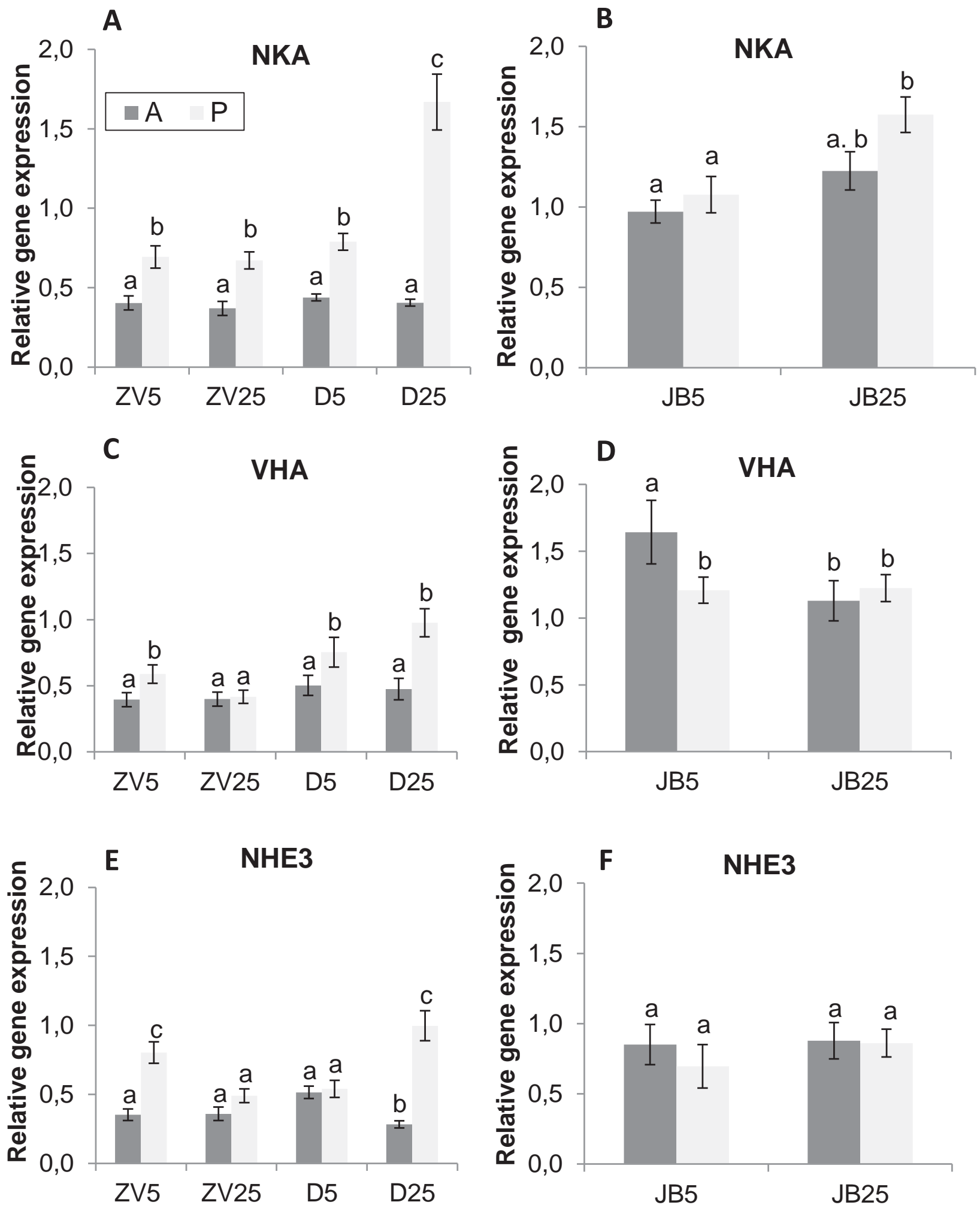
Fig. 2

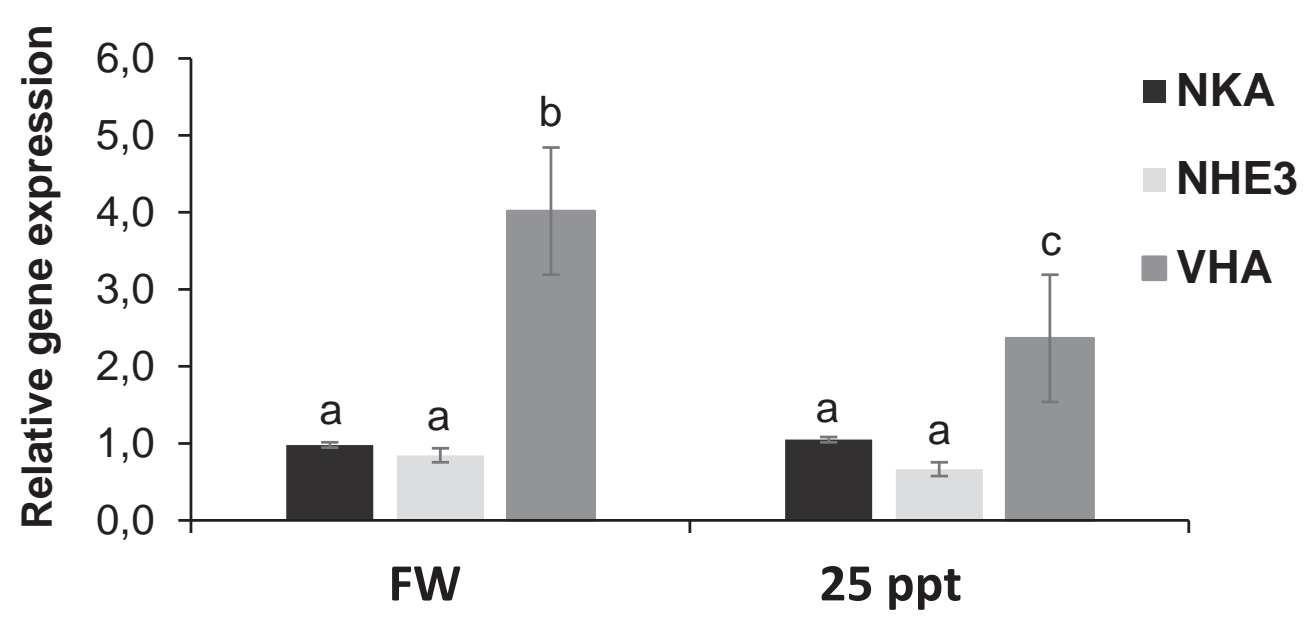


Table 1 :

\begin{tabular}{|c|c|c|c|c|}
\hline Primer name & Nucleotide sequences (from 5' to 3') & Use & Expected size & Efficiency \\
\hline EFd-F & GARTTYGARGCYGGTATCTC & CS & \multirow{2}{*}{$\begin{array}{l}495 \mathrm{bp} \\
\text { (Ituarte et al., in } \\
\text { press) }\end{array}$} & \multirow[t]{2}{*}{-} \\
\hline EFd-R & GGWGGTATTGGWACWGTGCCC & CS & & \\
\hline NHE3d-F2 & GGYTTCCACATGACKCCGAAG & CS & \multirow[t]{2}{*}{262 bp } & \multirow[t]{2}{*}{-} \\
\hline NHE3d-R3 & GGGCGTWCAGAGAGATTCCG & CS & & \\
\hline EF-F4 & CAACCCAGCCATTGTACCCATC & qPCR & \multirow[t]{2}{*}{$163 \mathrm{bp}$} & \multirow[t]{2}{*}{1.938} \\
\hline EF-R4 & GGGCTCGATGTTGTCCAGAGC & qPCR & & \\
\hline VHA-F1 & TTCCTTCTACTCGACCGGCACG & qPCR & \multirow{2}{*}{$\begin{array}{l}81 \mathrm{bp} \\
\text { (Faleiros et al., } \\
2010 \text { ) }\end{array}$} & \multirow[t]{2}{*}{1.999} \\
\hline VHA-R1 & TGCCAGGTAGACGTGGTTTCCC & qPCR & & \\
\hline NHE3-F4 & GAAGGCGGCATCGGTGTCC & qPCR & \multirow[t]{2}{*}{$121 \mathrm{bp}$} & \multirow[t]{2}{*}{1.997} \\
\hline NHE3-R7 & CGTGCCCAGGTGGTCGAAG & qPCR & & \\
\hline NKA-F3 & TACACGCTCACCAAGACCTCCC & qPCR & \multirow{2}{*}{$\begin{array}{l}102 \text { bp } \\
\text { (Faleiros et al., } \\
\text { 2010) }\end{array}$} & \multirow[t]{2}{*}{1.946} \\
\hline NKA-R3 & TGGCTTGCGGTGATGTTAAGGG & qPCR & & \\
\hline
\end{tabular}


Table 2 :

\begin{tabular}{|c|c|c|c|c|}
\hline Protein & Species & $\begin{array}{l}\text { Accession } \\
\text { number }\end{array}$ & $\begin{array}{l}\text { Query } \\
\text { cover } \\
\text { (\%) }\end{array}$ & $\begin{array}{l}\text { Amino acid } \\
\text { homology (\%) }\end{array}$ \\
\hline \multirow{4}{*}{$\begin{array}{l}\text { Elongation } \\
\text { factor } 1 \alpha \\
(\text { EF1 } \alpha)\end{array}$} & $\begin{array}{l}\text { Macrobrachium } \\
\text { rosenbergii }\end{array}$ & AGW23427.1 & 100 & 95 \\
\hline & Palaemon argentinus & AIW04742.1 & 98 & 91 \\
\hline & Penaeus monodon & AIS67294.1 & 100 & 85 \\
\hline & Scylla paramamosain & AFN08747.1 & 100 & 88 \\
\hline \multirow{4}{*}{$\begin{array}{l}\text { Sodium- } \\
\text { hydrogen } \\
\text { exchanger } \\
3 \text { (NHE3) }\end{array}$} & Cherax destructor & AJ070016.1 & 97 & 63 \\
\hline & Amyelois transitella & XP_013190821.1 & 97 & 63 \\
\hline & $\begin{array}{l}\text { Cherax } \\
\text { quadricarinatus }\end{array}$ & AIW68618.1 & 97 & 62 \\
\hline & Plutella xylostella & $\begin{array}{l}\text { XP_011563892.1 } \\
\text { XP_011563894.1 }\end{array}$ & 97 & 69 \\
\hline
\end{tabular}

